\title{
Pelatihan dan Pendampingan Pemanfaatan Eceng gondok (Eichornia crassipes) Menjadi Pupuk Kompos Cair Untuk Mengurangi Pencemaran Air dan Meningkatkan Ekonomi Masyarakat Desa Karangkimpul Kelurahan Kaligawe Kecamatan Gayamsari Kotamadya Semarang
}

\author{
Kusrinah, Alwiyah Nurhayati, Nur Hayati \\ Universitas Islam Negeri Walisongo Semarang
}

\begin{abstract}
Abstrak : Hyacinth (Eichornia crassipes) is known as one of the weeds that have grown high speed so potentially damaging to the aquatic environment. Presence at the water hyacinth has its own important values associated with the sustainability of aquatic ecosystems, namely as a producer. Community service activities aims to provide training and mentoring utilization of water hyacinth into liquid compost to reduce water pollution and improve the local economy Karangkimpul Village Kaligawe Gayamsari District Semarang City. Location of community service is an area of marsh overgrown with water hyacinth. Community service that has been taken is focused on how simple and appropriate technology can be used by the public through the processing of water hyacinth into products such as liquid compost. The debriefing is given in the form of the theory and practice of composting, packaging and product marketing strategies. Liquid compost product made from the water hyacinth is expected to support the national fertilizer demand and improve people's lives.
\end{abstract}

Key words: hyacinth, liquid compost, economic level of society.

Abstrak : Eceng gondok (Eichornia crassipes) dikenal sebagai
salah satu gulma yang memiliki kecepatan tumbuh yang
tinggi sehingga berpotensi merusak lingkungan perairan.
Keberadaan eceng gondok di perairan memiliki nilai penting
tersendiri terkait dengan keberlangsungan ekosistem perairan
yaitu sebagai produsen. Kegiatan pengabdian masyarakat ini
bertujuan untuk memberikan pelatihan dan pendampingan
pemanfaatan eceng gondok menjadi pupuk kompos cair
untuk mengurangi pencemaran air dan meningkatkan 
ekonomi masyarakat Desa Karangkimpul Kelurahan Kaligawe Kecamatan Gayamsari Kota Semarang. Lokasi pengabdian masyarakat merupakan daerah rawa yang banyak ditumbuhi eceng gondok. Pengabdian masyarakat yang telah ditempuh ini menitikberatkan pada bagaimana teknologi sederhana dan tepat guna dapat digunakan oleh masyarakat melalui pengolahan eceng gondok menjadi produk berupa pupuk kompos cair. Pembekalan yang diberikan kepada masyarakat berupa teori dan praktik pembuatan pupuk kompos, pengemasan dan strategi pemasaran produk. Produk pupuk kompos cair berbahan dasar eceng gondok diharapkan dapat mendukung kebutuhan pupuk nasional dan meningkatkan taraf hidup masyarakat Desa Karangkimpul Kecamatan Gayamsari Kota Semarang.

Kata kunci : eceng gondok, pupuk kompos cair, taraf ekonomi masyarakat

\section{PENDAHULUAN}

Eceng gondok (Eichornia crassipes) dikenal sebagai salah satu gulma yang memiliki kecepatan tumbuh yang tinggi sehingga dapat merusak lingkungan perairan antara lain meningkatkan evapotranspirasi (penguapan dan hilangnya air melalui daun-daun tanaman), menurunkan jumlah cahaya yang masuk kedalam perairan sehingga menyebabkan menurunnya tingkat kelarutan oksigen dalam air, mempercepat terjadinya proses pendangkalan, mengganggu lalu lintas air, meningkatkan habitat bagi vektor penyakit pada manusia serta menurunkan nilai estetika lingkungan perairan.

Keberadaan eceng gondok di perairan memiliki nilai penting tersendiri terkait dengan keberlangsungan ekosistem perairan yaitu sebagai produsen. Allah SW'T menciptakan segala sesuatu pasti ada manfaatnya, begitu juga dengan eceng gondok. Eceng gondok merupakan karunia Allah yang patut disyukuri dan dimanfaatkan semaksimal mungkin. Allah SWT berfirman dalam surat al-Qoof ayat $7 \& 8$ yang artinya:

"Dan Kami hamparkan bumi itu dan Kami letakkan padanya gununggunung yang kokoh dan Kami tumbuhkan padanya segala macam tanaman yang 
indah dipandang mata. untuk menjadi pelajaran dan peringatan bagi tiap-tiap hamba yang kembali (mengingat Allah)". ${ }^{1}$

Beberapa penelitian menunjukkan bahwa Eceng gondok dapat dijadikan sebagai sumber bahan organik alternatif. Hasil penelitian yang dilakukan di India menunjukkan bahwa eceng gondok yang masih segar mengandung 95,5\% air; 3,5\% bahan organik; $0,04 \%$ nitrogen; $1 \%$ abu; $0,06 \%$ fosfor sebagai P2O5 dan 0,20\% kalium sebagai K2O. Lebih lanjut dikemukakan pula bahwa percobaan analisis kimia tumbuhan eceng gondok atas dasar bahan kering menghasilkan 75,8 \% bahan organik; 1,5\% nitrogen; dan 24,2\% abu. Analisis terhadap abu yang dilakukan menunjukkan $7.0 \%$ fosfor sebagai $\mathrm{P}_{2} \mathrm{O}_{5} ; 28,7 \%$ kalium sebagai $\mathrm{K}_{2} \mathrm{O} ; 1,8 \%$ natrium sebagai $\mathrm{Na}_{2} \mathrm{O} ; 12,8 \%$ kalsium sebagai $\mathrm{CaO}$ dan 21,0\% khlorida CCL5.

Dengan kandungan bahan organik dan unsur hara yang tinggi tersebut eceng gondok dapat dijadikan sebagai alternatif sumber pupuk kompos. Pupuk kompos cair merupakan salah satu pupuk organik yang praktis dan sangat mudah pembuatannya. Kelebihan pupuk kompos cair daripada pupuk yang lain adalah mampu menyediakan hara secara cepat dan ramah terhadap lingkungan karena tidak merusak tanah walaupun digunakan sesering mungkin. ${ }^{2}$

Pengabdian masyarakat yang telah ditempuh ini menitikberatkan pada bagaimana teknologi yang mudah, murah dan tepat guna dapat digunakan oleh masyarakat Desa Karangkimpul kecamatan Gayamsari Semarang untuk mengolah eceng gondok menjadi produk yang mempunyai daya guna yang lebih tinggi. Produk yang disasar pada pengabdian ini adalah dengan menjadikan enceng gondok sebagai pupuk kompos cair sehingga mendukung kebutuhan pupuk nasional dan meningkatkan taraf hidup masyarakat di sekitar rawa di Karang Kimpul Kelurahan Kaligawe.

\section{Analisis situasi}

Desa Karangkimpul, Kecamatan Gayamsari Kotamadya Semarang terletak bagian utara kota Semarang. Kondisi desa seringkali terkena rob sehingga lahan pertanian yang tadinya ditanami padi berubah fungsi menjadi rawa untuk memelihara ikan.

${ }^{1}$ Tim Penyusun Departemen Agama RI, 2006. Al-Qur'an dan Terjemahannya, Penerbit Diponegoro. Bandung

2 Alex S. 2012. Sukses Mengolah Sampah Organik Menjadi Pupuk organik. Pustaka Baru Press.Yogyakarta. 
Adapun profil singkat desa karangkimpul kelurahan kaligawe adalah sebagai berikut:

Luas wilayah

: 108.88 ha

Luas daerah rawa

: 15 ha

Luas rawa yang ditumbuhi eceng gondok : 80\% x 15 ha $=12$ ha

Jumlah penduduk laki-laki

: 3868 jiwa

Jumlah penduduk perempuan

: 3581 jiwa

Pada perkembangan selanjutnya rawa tersebut ditumbuhi eceng gondok yang pertumbuhannya sangat pesat. Keberadaan eceng gondok yang sangat melimpah ini merugikan perikanan setempat karena mengurangi jumlah oksigen terlarut sehingga banyak ikan yang mati. Beberapa upaya telah dilakukan untuk memanfaatkan eceng gondok supaya mempunyai nilai ekonomi yang tinggi antara lain untuk pakan ternak namun pemanfaatan eceng gondok untuk pakan ternak kurang efektif karena memiliki banyak kelemahan antara lain kadar airnya masih sangat tinggi dan proteinnya sulit dicerna sehingga perlu dilakukan upaya pemanfaatan potensi lain yaitu sebagai sumber pupuk kompos cair.

\section{Kondisi dampingan yang diharapkan}

Setelah mengikuti pelatihan dan pendampingan pengolahan eceng gondok menjadi pupuk kompos cair diharapkan masyarakat desa Karang kimpul terampil dalam mengolah eceng gondok sehingga mempunyai nilai guna dan nilai jual yang lebih tinggi. Eceng gondok yang semula menjadi sumber pencemaran air dapat dimanfaatkan menjadi pupuk kompos cair yang kaya akan Nitrogen. Pupuk kompos cair ini dapat menjadi salah satu altenatif pengganti pupuk kompos padat sehingga dapat mengurangi ketergantungan masyarakat terhadap pupuk kompos padat dan dapat mengurangi masalah pencemaran air di desa karang kimpul. Selain itu, melalui penelitian ini masyarakat juga akan dilatih bagaimana teknik pemasaran pupuk kompos cair. Hal ini sangat penting agar pupuk kompos cair yang telah masyarakat hasilkan dapat dipasarkan sehingga dapat membanntu meningkatkan perekonomian masyarakat.

Keuntungan (benefit) yang bisa diperoleh dari kegiatan ini antara lain adalah:

Keuntungan (benefit) ditinjau dari sisi ekologi:

- Mengurangi pencemaran lingkungan (perairan)

- Menanggulangi penyebaran penyakit

- Memperbaiki ekosistem sehingga bisa kembali pada kondisi semula yang siap untuk dijadikan lahan budidaya ikan dan pertanian 
Keuntungan (benefit) ditinjau dari sisi ekonomi:

- Menambah atau meningkatkan taraf ekonomi masyarakat baik dari hasil penjualan pupuk kompos juga dari hasil lahan pertanian dan perikanan

- Menciptakan lapangan kerja baru dengan produksi pupuk kompos cair

Keuntungan (benefit) ditinjau dari sisi sosial budaya:

- Dengan adanya kegiatan ini diharapkan bisa memotivasi masyarakat untuk menerapkan teknologi tepat guna yang ramah lingkungan

- Mengubah mindset masyarakat tentang gulma yang bisa dikelola menjadi bahan yang lebih bermanfaat

\section{LANDASAN TEORI DAN STRATEGI}

\section{Eceng Gondok (Eichornia crassipes)}

Eceng gondok merupakan salah satu jenis tanaman air dengan ciri fisik tinggi tanaman sekitar 0,4-0,8 meter. Ciri fisik lain yaitu daun eceng gondok tergolong dalam makrofita yang terletak di atas permukaan air, yang di dalamnya terdapat lapisan rongga udara dan berfungsi sebagai alat pengapung tanaman. Daunnya tunggal dan berwarna hijau, memiliki bentuk oval, ujung dan pangkalnya meruncing, pangkal tangkai daun berbentuk gelembung, permukaan daun licin. Gelembung dalam batang eceng gondok di dalamnya penuh dengan udara yang berperan untuk mengapungkan tanaman di permukaan air. Lapisan terluar petiole merupakan lapisan epidermis. Pada bagian bawah terdapat jaringan tipis sklerenkim dengan bentuk sel yang tebal (parenkim). Di dalam jaringan parenkim terdapat jaringan pengangkut (xylem dan floem). Ronggarongga udara di dalam batang dibatasi oleh dinding penyekat berupa selaput tipis berwarna putih. ${ }^{3}$

Sistem perakaran tanaman eceng gondok adalah akar serabut. Sistem akar serabut memiliki fungsi sebagai pegangan atau jangkar tanaman. Akar berperan untuk menyerap zat-zat yang diperlukan tanaman dari dalam air. Di bagian ujung akar terdapat kantung akar berwarna merah, susunan akarnya dapat mengumpulkan lumpur atau partikel-partikel yang terlarut dalam air. Bunga eceng gondok termasuk dalam klasifikasi bunga majemuk dan bertangkai. Beberapa ciri morfologis dari bunga eceng gondok antara lain berbentuk karangan bunga bulir, kelopaknya berbentuk tabung, warna mahkota lembayung

3 Pandey.B.P.1980. Plant Anatomi, New Delhi: S Chard dan Co, Ltdramnage. 
muda. Biji tanaman eceng gondok memiliki bentuk bulat dan berwarna hitam. Sedangkan buah eceng gondok berbentuk kotak beruang tiga dan berwarna hijau. ${ }^{4}$

Beberapa manfaat tanaman eceng gondok (Eichornia crassipes) antara lain:

1. Sebagai biomonitoring

Eceng gondok sebagai biomonitoring pencemaran logam berat Cadmium (Cd) dan plumbum $(\mathrm{Pb})$ dengan tingkat akumulasi terbanyak pada organ batang. ${ }^{5}$

2. Sebagai fitoremediasi

Eceng gondok dapat digunakan sebagai fitoremediasi. Dalam waktu 24 jam eceng gondok mampu menyerap logam kadmium (Cd), merkuri (Hg), dan nikel (Ni), masing-masing sebesar 1,35 mg/g, 1,77mg/g, dan 1,16 mg/g bila logam itu tak bercampur. Eceng gondok juga menyerap Cd 1,23 mg/g, Hg 1,88 mg/g dan $\mathrm{Ni} 0,35 \mathrm{mg} / \mathrm{g}$ berat kering apabila logam-logam itu berada dalam keadaan tercampur dengan logam lain. Logam chrom (Cr) dapat diserap oleh eceng gondok secara maksimal pada $\mathrm{pH}$ 7. Eichornia crassipes juga dapat digunakan sebagai fitoremediasi terhadap cesium (Cs) dengan akumulasi tertinggi pada bagian batang dan daun. Selain dapat menyerap logam berat, eceng gondok dilaporkan juga mampu menyerap residu pestisida.

3. Sebagai pakan ternak

Eceng gondok dapat digunakan sebagai campuran pakan ternak unggas.

4. Sebagai bahan pembuat kerajinan tangan : tikar, tas dan jenis bahan kerajinan yang lainnya.

\section{Pupuk}

Pupuk merupakan bahan yang ditambahkan ke dalam tanah dan berperan sebagai penyedia unsur hara yang penting bagi pertumbuhan tanaman. Pada umumnya pengklasifikasian pupuk didasarkan pada sumber bahan yang digunakan, cara aplikasi, bentuk dan kandungan unsur haranya.

Jika diklasifikasikan berdasarkan bentuknya, pupuk organik dibedakan menjadi dua, yaitu pupuk cair dan padat.

Pupuk cair adalah larutan yang berisi satu atau lebih pembawa unsur (bahan mudah larut) yang dibutuhkan tanaman. Beberapa kelebihan pupuk cair

${ }^{4}$ Ardiwinata.R.O. 1985. Musub Dalam Selimut di Rawa Pening. Bandung: KementrianPertanian, Vorking

${ }^{5}$ Kholidiyah, Noviana. 2010. Respon Biologis Tumbuhan Eceng gondok (Eichornia crassipes Solms) Sebagai Biomonitoring Pencemaran Logam Berat Cadmium (Cd) Dan Plumbum (Pb) pada Sungai Pembuangan Lumpur Lapindo, Kecamatan Porong, Kabupaten Sidoarjo. UIN Maliki Malang. 
diantaranya adalah mampu memberikan hara sesuai kebutuhan tanaman, pemberiannya dapat lebih merata dan kepekatannya dapat diatur sesuai kebutuhan tanaman.

Ditinjau dari sumber bahan yang digunakan, pupuk dapat dikategorikan menjadi pupuk anorganik dan pupuk organik. Pupuk anorganik adalah pupuk yang berasal dari bahan mineral dan diproses produksi di pabrik sehingga menjadi senyawa kimia baru yang mudah diserap tanaman. Sedangkan pupuk organik adalah pupuk yang terbuat dari bahan organik atau makhluk hidup yang telah mati. Selanjutnya bahan organik ini akan mengalami pembusukan oleh mikroorganisme sehingga sifat fisiknya akan berbeda dari kondisi semula. Pupuk organik memiliki kandungan unsur haranya lebih dari satu unsur dan mengandung unsur mikro sehingga termasuk pupuk majemuk lengkap. Jika ditinjau dari bentuknya, pupuk organik dibedakan menjadi dua, yakni pupuk organik padat dan cair.

a.Pupuk Organik padat

Pupuk organik padat adalah pupuk yang sebagian besar atau seluruhnya terdiri atas bahan organik padat. Bahan padat dapat berasal dari sisa tanaman, kotoran hewan, dan manusia. Jika ditinjau bahan asalnya, pupuk organik padat dikategorikan lagi menjadi pupuk kandang, humus, kompos dan pupuk hijau.

1. Pupuk Kandang

Pupuk kandang adalah jenis pupuk organik yang berbahan dasar kotoran ternak, baik kotoran padat maupun campuran sisa makanan dan air seni ternak. Kotoran yang dihasilkan hewan kambing, domba, sapi, ayam merupakan kotoran yang paling sering digunakan untuk dijadikan pupuk kandang.

Selain berperan membantu pertumbuhan, pupuk kandang juga dapat membantu menetralkan racun logam berat di dalam tanah. Pupuk kandang juga berperan dalam perbaikan struktur tanah, pengoptimalan penyerapan unsur hara dan mempertahankan suhu tanah. Beberapa ciri fisik pupuk kandang yang telah siap digunakan antara lain dingin, remah, wujud aslinya sudah tidak tampak, dan baunya telah berkurang. Ciri-ciri tersebut merupakan hal mutlak agar pupuk kandang bisa digunakan. Penggunaan pupuk kandang biasanya dilakukan dengan cara disebar dan dibenamkan. Cara penggunaan yang paling baik adalah dibenamkan karena dengan cara tersebut penguapan unsur hara akibat proses kimia dalam tanah dapat dikurangi.

2. Pupuk Hijau

Pupuk hijau merupakan jenis pupuk organik yang berbahan dasar tanaman atau bagian tanaman tertentu yang masih segar kemudian dibenamkan ke dalam tanah. Daun, tangkai dan batang yang masih muda merupakan bagian 
tanaman yang sering digunakan sebagai pupuk hijau. Jenis tanaman yang paling bagus untuk pupuk hijau adalah jenis tanaman yang akarnya bersimbiosis dengan mikroorganisme pengikat nitrogen. Pupuk hijau berperan dalam meningkatkan kuantitas bahan organik tanah dan unsur hara, khususnya nitrogen.

3. Humus

Humus merupakan jenis pupuk organik yang merupakan hasil dekomposisi tumbuhan berupa daun, akar, cabang, ranting dan bahan secara alami. Proses dekomposisi dibantu oleh mikroorganisme tanah. Cuaca merupakan faktor yang sangat berpengaruh dalam keberhasilan proses dekomposisi. Perbedaannya antara humus dan pupuk hijau hanya terletak pada prosesnya. Humus terbentuk melalui proses dekomposisi alami dan sebagian besar terjadi dihutan sedangkan pupuk hijau terbentuk dengan bantuan proses yang dilakukan oleh manusia. ${ }^{6}$

\section{Kompos}

Kompos merupakan salah satu jenis pupuk organik yang dibuat dari proses penguraian sisa-sisa tanaman dan hewan dengan bantuan organisme hidup. Bahan baku utama pembuatan pupuk kompos yaitu material organik dan organisme pengurai. Organisme pengurai yang digunakan bisa berupa mikroorganisme ataupun makroorganisme.

Teknologi pengomposan dikembangkan dari proses penguraian material organik yang terjadi secara alami sebagaimana yang terjadi pada humus sehingga pengomposan yang dikelola manusia bisa dilakukan dalam tempo yang lebih singkat.

Pupuk kompos dapat dibuat dengan cara yang mudah dan teknologinya sederhana. Pembuatan pupuk kompos dapat dilakukan oleh semua orang dalam skala besar untuk skala pertanian maupun skala kecil yaitu sekadar keperluan pekarangan.

Peranan pupuk kompos selain berperan untuk menyediakan nutrisi bagi tanaman, juga dapat memperbaiki struktur fisik, kimia dan biologi tanah. Kompos berperan dalam peningkatan kemampuan tanah untuk menyimpan air sebagai cadangan di saat kekeringan. Selain itu kompos juga dapat membuat tanah menjadi gembur sehingga cocok sebagai media tumbuh akar tanaman. Kompos dapat digunakan sebagai perekat pada tanah tipe pasir sehingga tanah menjadi lebih solid. Kompos berfungsi sebagai penggembur tanah liat agar tidak terlalu padat.

${ }^{6}$ Hadisuwito, S. 2007. Membuat Pupuk Kompos Cair. AgroMedia Pustaka. Yogyakarta 
Ditinjau dari sifat kimia, pupuk kompos bisa meningkatkan kapasitas tukar kation dalam tanah yang berfungsi melepaskan unsur-unsur penting agar bisa diserap dengan mudah oleh tanaman.

Ditinjau secara biologi, pupuk kompos merupakan media yang baik bagi organisme tanah untuk berkembang biak sehingga dengan adanya aktivitas mikroorganisme dan satwa tanah akan memperkaya tanah dengan zat hara penting bagi tanaman.

Beberapa ciri-ciri umum pupuk kompos yang baik adalah sebagai berikut: (1) Tidak berbau busuk, memiliki bau yang sama dengan tanah, (2) Warna coklat kehitaman, berbentuk butiran gembur seperti tanah, (3) Jika dimasukkan ke dalam air seluruhnya tenggelam, dan air tetap jernih tidak berubah warna, (4) Jika diaplikasikan pada tanah tidak memicu tumbuhnya gulma.

Proses penguraian material organik oleh mikroorganisme dan satwa tanah berjalan dengan reaksi aerob dan anaerob silih berganti.

Pada proses aerob, proses pengomposan yang terjadi tidak menimbulkan bau busuk dan akan melepaskan energi dalam bentuk panas. Pelepasan energi mengakibatkan kenaikan suhu yang tepat sangat menguntungkan bagi lingkungan mikroba aerob. Suhu proses pengomposan dipayakan tidak melebihi $65^{\circ} \mathrm{C}$ karena apabila panas melebihi $65^{\circ} \mathrm{C}$ maka akan menyebabkan kebanyakan mikroba akan mati dan proses pengomposan berjalan lambat bahkan bisa terjadi pembusukan. Penurunan suhu pengomposan dilakukan dengan cara diaduk atau dibalik.

Proses anaerob reaksi berlangsung dalam beberapa tahap. Pada tahap pertama, terjadi penguraian bahan organik dilakukan oleh bakteri fakultatif menjadi asam lemak. Kemudian tahap kedua, asam lemak diubah oleh kelompok mikroba lain menjadi amoniak, metan, karbondioksida dan hidrogen.

Proses pembuatan pupuk kompos cair adalah sebagai berikut: ${ }^{7}$

a. Siapkan bahan-bahan berikut: 1 karung kotoran ayam, setengah karung dedak, $30 \mathrm{~kg}$ eceng gondok, 100 gram gula merah, $50 \mathrm{ml}$ bioaktivator (EM4), air bersih secukupnya.

b. Siapkan tong plastik kedap udara ukuran 100 liter sebagai media pembuatan pupuk, satu meter selang aerotor transparan (diameter kira-kira 0,5 cm), botol plastik bekas aqua ukuran 1 liter. Lubangi tutup tong seukuran selang aerotor.

c. Potong atau rajang eceng gondok masukkan kedalam tong dan tambahkan

${ }^{7}$ Sugeng, Wahyudi. 2013. Bikin Kompos dari Eceng Gondok.

http://rajakomposcair.blogspot.com/. Diakses tanggal 20 April 2015 
air, komposisinya: 2 bagian eceng gondok, 1 bagian air. Kemudian adukaduk hingga merata.

d. Larutkan bioaktivator seperti EM4 dan gula merah 5 liter air aduk hingga merata. Kemudian tambahkan larutan tersebut ke dalam tong yang berisi bahan baku pupuk.

e. Tutup tong dengan rapat, lalu masukan selang lewat tutup tong yang telah diberi lubang. Rekatkan tempat selang masuk sehingga tidak ada celah udara. Biarkan ujung selang yang lain masuk kedalam botol yang telah diberi air.

f. Pastikan benar-benar rapat, karena reaksinya akan berlangsung secara anaerob. Fungsi selang adalah untuk menyetabilkan suhu adonan dengan membuang gas yang dihasilkan tanpa harus ada udara dari luar masuk ke dalam tong.

g. Tunggu hingga 7-10 hari. Untuk mengecek tingkat kematangan, buka penutup tong cium bau adonan. Apabila wanginya seperti wangi tape, adonan sudah matang.

h. Pisahkan antara cairan dengan ampasnya dengan cara menyaringnya. Gunakan saringan kain. Ampas adonan bisa digunakan sebagai pupuk organik padat.

i. Masukkan cairan yang telah melewati penyaringan pada botol plastik atau kaca, tutup rapat. Pupuk organik cair telah jadi dan siap digunakan. Apabila dikemas baik, pupuk bisa digunakan sampai 6 bulan.

\section{PELAKSANAAN}

Pemanfaatan eceng gondok menjadi pupuk kompos cair bermanfaat untuk mengurangi pencemaran air, meningkatkan nilai guna dari eceng gondok, dan dapat meningkatkan kesejahteraan masyarakat. Oleh karena itu, perlu dilakukan pelatihan dan pendampingan pengolahan eceng gondok menjadi pupuk kompos cair kepada masyarakat Desa karang kimpul, Kecamatan Gayam sari, Kotamadya Semarang. Berikut ini adalah tahapan pengabdian :

Persiapan

Pada tahap persiapan dilakukan observasi terhadap potensi Desa karangkimpul. Bagaimana cara pengolahan potensi tersebut dan adakah limbah yang dihasilkan potensi tersebut. Ternyata eceng gondok belum dimanfaatkan untuk kesejahteraan masyarakat. Pada tahap persiapan juga dilakukan eksperimen di laboratorium.

Pelaksanaan

Proses pelaksanaan terbagi menjadi 2, yaitu: 


\section{a. Sosialisasi}

Tahap ini bertujuan untuk memberikan pengetahuan kepada masyarakat mengenai pengolahan limbah eceng gondok menjadi pupuk kompos cair yang mempunyai nilai jual tinggi dan bagaimana teknik pemasarannya.

Berikut manual acara yang dilaksanakan:

\begin{tabular}{|c|c|c|c|c|}
\hline No & Hari & Waktu & Acara & Pembicara \\
\hline 1. & Minggu & $\begin{array}{l}09.00- \\
\text { selesai }\end{array}$ & $\begin{array}{l}\text { Sosialisasi pengolahan } \\
\text { eceng gondok menjadi } \\
\text { pupuk kompos cair }\end{array}$ & Dr. Lianah, M.Pd \\
\hline
\end{tabular}

b. Pelatihan

Pelatihan pemanfaatan eceng gondok menjadi pupuk kompos cair dilakukan secara praktik langsung. Peserta dibagi menjadi beberapa kelompok kecil untuk bekerja bersama-sama membuat pupuk kompos cair. Instruktur dan asisten ahli disediakan untuk membantu belajar para peserta.

\begin{tabular}{|l|l|l|l|l|}
\hline No & Hari & Waktu & Acara & Pembicara \\
\hline 1. & Minggu & 09.00 & $\begin{array}{l}\text { Praktik Pembuatan eceng } \\
\text { gondok menjadi pupuk cair }\end{array}$ & Kusrinah, M.Si \\
\hline 2. & Minggu & $\begin{array}{l}\text { 09.00- } \\
\text { selesai }\end{array}$ & $\begin{array}{l}\text { Pengemasan dan Teknik } \\
\text { Pemasaran }\end{array}$ & $\begin{array}{l}\text { M. Agus } \\
\text { Guntoro, S.Pd }\end{array}$ \\
\hline
\end{tabular}

c. Pasca Pelaksanaan

Setelah melakukan praktik pembuatan pupuk kompos cair selanjutnya dilakukan kegiatan sosialisasi tentang pengemasan dan teknik pemasaran produk.

\begin{tabular}{|l|l|l|l|l|}
\hline No & Hari & Waktu & Acara & Pembicara \\
\hline 1. & Minggu & $\begin{array}{l}\text { 09.00- } \\
\text { selesai }\end{array}$ & $\begin{array}{l}\text { Pengemasan dan Teknik } \\
\text { Pemasaran }\end{array}$ & $\begin{array}{l}\text { M. Agus Guntoro, } \\
\text { S.Pd }\end{array}$ \\
\hline
\end{tabular}

\section{Implementasi Kegiatan}

Kegiatan awal yang dilakukan adalah penelitian dalam skala laboratorium dengan membuat pupuk kompos cair dalam skala kecil.

Kegiatan awal yang dilakukan adalah penelitian dalam skala laboratorium dengan membuat pupuk kompos cair (PKC) dalam skala kecil. Dalam penelitian awal ini dilakukan dengan memvariasi bahan yaitu satu sampel menggunakan 
larutan EM4-mollase dan satu sampel yang lain menggunakan larutan EM4-gula jawa. Bahan organik berupa eceng gondok dengan mengambil semua bagian dari tanaman yang masih dalam kondisi segar yaitu daun, batang dan akar dirajang hingga menjadi ukuran kecil. Selanjutnya dilakukan penimbangan bahan eceng gondok dengan menggunakan neraca digital sesuai dengan takaran yang ada di dalam resep. Pada tahap berikutnya, bahan eceng gondok diperkecil lagi ukurannya dengan cara digiling dengan menggunakan blender dengan menggunakan sedikit air. Hal ini dilakukan untuk mempercepat proses pembuatan PKC.

Eceng gondok yang telah digiling berbentuk seperti pasta. Selain itu juga dilakukan penyiapan larutan EM4-mollase, larutan EM4-gula jawa, air dan penimbangan bahan-bahan yang lain diantaranya kotoran kambing dan dedak. Peralatan yang digunakan dalam penelitian ini yaitu toples plastik ukuran 5 liter, selang $0,5 \mathrm{~m}$, pengaduk dan botol air mineral.

Tahap selanjutnya adalah proses pencampuran bahan-bahan yaitu pasta eceng gondok, kotoran kambing dan dedak sesuai dengan takaran yang ada di dalam resep ke dalam dua toples plastik yang berbeda. Adapun peran dari masing-masing bahan yang digunakan yaitu eceng gondok berfungsi sebagai substrat, kotoran kambing berfungsi sebagai sumber mikroba, dan dedak berfungsi sebagai nutrisi untuk mikroba.

Setelah bahan padat tercampur, selanjutnya dilakukan penuangan EM4mollase sampel pertama dan penuangan larutan EM4-gula jawa untuk sampel yang kedua. Peranan dari larutan EM4 dalam pembuatan PKC adalah sebagai mikroba, sedangkan peranan mollase dan larutan gula jawa adalah sebagai nutrient.

Bahan terakhir yang dituangkan ke dalam toples sampel adalah air. Air selain berfungsi untuk memudahkan dalam proses pencampuran bahan-bahan PKC, juga berperan sebagai stabilisator suhu.

Tahap berikutnya adalah pengadukan bahan-bahan PKC dilakukan untuk mendapatkan campuran bahan yang homogen. Selain itu disiapkan botol air mineral yang berisi air setengah bagiannya dan tutup dari toples. Tutup botol air dan tutup toples diberi lubang untuk tempat masuknya selang penghubung antara botol yang berisi air dengan toples yang berisi bahan sampel.

Tahap terakhir adalah penyimpanan sampel untuk proses fermentasi. Kedua sampel didiamkan selama kurang lebih 7-10 hari untuk menjalani proses fermentasi ini. 
Setelah melalui proses fermentasi selama 7-10 hari, toples yang berisi sampel dibuka kemudian dilakukan penyaringan untuk memisahkan komponen cair dan komponen padat dari pupuk kompos.

Berdasarkan penelitian yang telah dilakukan maka didapatkan hasil yang berupa tebel sebagai berikut:

Tabel 1. Tabel pengamatan pupuk cair organik hari ke 10 fermentasi

\begin{tabular}{|c|l|l|}
\hline Sampel & \multicolumn{1}{|c|}{ Perlakuan bahan } & \multicolumn{1}{c|}{ Hasil pengamatan } \\
\hline 1 & kotoran kambing & Bau: berbau menyengat \\
& eceng gondok & Warna: coklat pekat \\
& dedak & Kepekatan: encer \\
& EM4 & Tekstur: Kasar \\
& mollase & Berjamur \\
\hline 2 & kotoran kambing & Bau: berbau menyengat \\
& eceng gondok & Warna: coklat pekat \\
& dedak & Kepekatan: encer \\
& EM4 & Tekstur: Kasar \\
& gula jawa & Berjamur \\
\hline
\end{tabular}

Tabel 2. Tabel pengamatan pupuk cair organik hari ke 20 fermentasi

\begin{tabular}{|c|l|l|}
\hline Sampel & \multicolumn{1}{|c|}{ Perlakuan bahan } & \multicolumn{1}{c|}{ Hasil pengamatan } \\
\hline 1 & $\begin{array}{c}\text { kotoran kambing } \\
\text { eceng gondok } \\
\text { dedak }\end{array}$ & $\begin{array}{l}\text { Bau: tidak begitu menyengat } \\
\text { Warna: coklat pekat }\end{array}$ \\
& EM4 & Kepekatan: encer \\
& mollase & Tekstur: Kasar \\
& kotoran kambing & Tidak berjamur \\
\hline 2 & eceng gondok & Bau: tidak begitu \\
& dedak & menyengat \\
& EM4 & Warna: coklat pekat \\
& gula jawa & Kepekatan: encer \\
& & Tekstur: Kasar \\
& Tidak berjamur \\
\hline
\end{tabular}

Hasil pembuatan pupuk selanjutnya diuji kandungannya di laboratorium.

Berdasarkan hasil penelitian yang dilakukan di laboratorium Biologi, diperoleh hasil untuk sampel 1 dan sampel 2 dari segi bau sangat menyengat, hal ini dimungkinkan karena adanya unsur tanaman yang membusuk pada saat dilakukan pembuatan pertama kali. Penyebab yang lain yaitu kurangnya kuantitas EM4 yang diberikan ke dalam masing-masing sampel. 
Sampel pupuk kompos cair kemudian diuji di laboratorium Balai Pengkajian Teknologi Pertanian (BPTP). Uji sampel meliputi uji unsur nitrogen $(\mathrm{N})$ dan fosfat $\left(\mathrm{P}_{2} \mathrm{O}_{5}\right)$.

Berdasarkan hasil pengujian, didapatkan data sebagai berikut:

Tabel 3. Tabel hasil pengujian pupuk cair organik hari ke 20 fermentasi

\begin{tabular}{|l|l|c|l|c|c|}
\hline No. & Parameter & Satuan & \multicolumn{1}{|c|}{ Metode } & Hasil & $\begin{array}{c}\text { Standard } \\
\text { Mutu }\end{array}$ \\
\hline 1. & N-Total & $\%$ & Kjedahl & 0.06 & $3-6$ \\
\hline 2. & $\mathrm{P}_{2} \mathrm{O}_{5}$ & $\%$ & Spektrofotometri & 0.07 & $3-6$ \\
\hline
\end{tabular}

Berdasarkan hasil pengujian diketahui bahwa PKC yang telah dibuat mengandung unsur $\mathrm{N}$ dan $\mathrm{P}_{2} \mathrm{O}_{5}$. Hal ini menunjukkan bahwa ternyata eceng gondok memliki potensi untuk dijadikan PKC. Nilai prosentase yang kecil menunjukkan bahwa proses fermentasi berjalan kurang sempurna. Adapun faktor penyebab dimungkinkan karena kuantitas dari EM4 yang diberikan masih kurang mencukupi.

Pupuk kompos cair merupakan pupuk yang fleksibel untuk diaplikasikan. Pemakaian PKC bisa disemprotkan pada daun maupun disiramkan melalui akar. Berdasarkan hasil studi literatur didapatkan beberapa ciri PKC yang bagus yang dapat digunakan sebagai bahan pembanding kelayakan PKC yang dibuat dalam penelitian ini, diantaranya;

- Pupuk organik cair yang bagus mengandung agensia hayati (mikroorganisme) yang menguntungkan tanaman terutama agensia hayati pengikat Nitrogen dan pengurai Phospat dan kalium. Pada penelitian awal ini dari sampel PKC dengan EM4 menunjukkan. Sedangkan sampel PKC dengan gula jawa menunjukkan. Unsur hara makro terutama NPK merupakan unsur hara yang wajib ada dan dibutuhkan tanaman dalam jumah yang cukup banyak.

- Pupuk organik cair yang bagus juga mengandung unsur hara mikro, karena unsur hara mikro sangat diperlukan tanaman walaupun walaupun jumlahnya sedikit. Namun dalam penelitian awal ini belum sampai pada tahap analisis unsur hara mikro. Analisis terhadap unsur tersebut akan dilakukan dalam penelitian lanjutan.

- Pupuk organik cair yang bagus mengandung hormon atau ZPT. Namun dalam penelitian awal ini belum dilakukan penambahan hormone atau ZPT. Pengembangan PKC akan dilakukan dalam penelitian lanjutan. 
- Pupuk organik cair yang bagus pasti akan mencantumkan kandungan C organiknya. Namun dalam penelitian awal ini belum sampai pada tahap analisis unsur tersebut. Analisis terhadap unsur tersebut akan dilakukan dalam penelitian lanjutan.

- Pupuk organik cair yang bagus biasanya mencantumkan tingkat keasamannya ( $\mathrm{pH}$ nya). Dalam penelitian ini $\mathrm{pH}$ dari $\mathrm{PKC}$ adalah 6 bersifat asam namun mendekati $\mathrm{pH}$ netral.

- Pupuk organik cair yang bagus akan mencantumkan ijin resmi dari kementrian pertanian, biasanya akan tercantum dalam kemasannya (merupakan nomor ijin dari surat yang dikeluarkan kementrian pertanian ). Karena masih dalam skala laboratorium dan harus melalui serangkaian proses uji maka untuk hal ini belum diuruskan.

- Pupuk organik cair yang bagus akan memiliki harga jual yang realistis (tidak terlalu mahal). Tahap ini akan diestimasi setelah dilakukan penghitungan terhadap semua biaya pembuatan PKC.

Dalam pembuatan pupuk cair ada beberapa hal yang dapat mempengaruhi tingkat keberhasilan dan tingkat kegagalannya, yang nantinya dapat mempercepat proses fermentasi. Beberapa hal yang dapat mempengaruhi tingkat keberhasilan dalam pembuatan pupuk cair diantaranya adalah: ${ }^{8}$

1. Suhu

Suhu merupakan faktor yang penting bagi kehidupan bakteri, bakteri hidup dalam kondisi suhu yang sangat beragam. Bakteri yang menguntungkan umumnya hidup pada suhu optimum bagi pertumbuhan mahluk hidup lainnya yakni berkisar $18^{\circ} \mathrm{C}-40^{\circ} \mathrm{C}$. Suhu lingkungan yang terlalu tinggi dapat mengakibatkan denaturasi atau kerusakan protein dan komponen sel lainnya pada bakteri dekomposer sehingga dapat mengakibatkan kematian. Sedangkan suhu yang terlalu rendah dapat mengakibatkan mobilitas bakteri terhambat, dan jika terjadi kenaikan suhu secara ekstrim bakteri akan mati.

Bakteri dekomposer populasinya sedikit atau berkurang dapat menghambat proses dekomposisi bahan, suhu yang terlalu tinggi juga berdampak negatif terhadap perkembangbiakan bakteri dekomposer. Pada suhu ekstrim bakteri yang dapat berkembang cenderung bakteri yang bersifat patogenik, jadi jika suhu terlalu tinggi besar kemungkinannya bahan terkontaminasi oleh bakteri patogenik.

${ }^{8}$ Kusumaningtyas, R. 2012. Pengelolaan Limbab Pertanian. Fakultas Pertanian. Universitas Jember. 
Dalam penelitian ini digunakan botol yang berisi air yang dihubungkan dengan selang ke drum yang berisi bahan PKC yang berfunsi sebagai penstabil suhu.

\section{Kelembaban}

Bakteri dapat berkembangbiak pada kondisi kelembaban yang relatif tinggi yakni RH mencapai $\pm 60 \%$, kelembaban tinggi berarti lingkungan cenderung berair, bakteri sangat menyukai pada kondisi lingkungan yang relatif berair. Dalam penelitian ini ditambahkan air yang berfungsi untuk menjaga kelembaban selama proses fermentasi. Untuk faktor kelembaban juga distabilkan dengan penggunaan air dalam botol.

3. Intensitas Cahaya

Untuk dapat berkembang biak dengan optimal media yang berisi fementasi bahan untuk pupuk cair sebaiknya diletakkan pada tempat yang tidak terkena sinar matahari secara langsung. Sinar matahari secara langsung dapat meningkatkan suhu pada media secara signifikan yang dapat merusak protein dan komponen sel lainnya, sitoplasma bakteri bocor sehingga bakteri dapat mengalami kematian yang berdampak pada lambatnya fermentasi bahakan bahan besar kemungkinannya tidak terfermentasi. Dalam penelitian ini, pada saat pembuatan PKC dilakukan dalam ruang terang, akan tetapi pada saat proses fermentasi dilakukan di dalam ruang gelap untuk meminimalisir interaksi dengan cahaya.

4. Ukuran bahan

Sumber makanan bakteri dekomposer adalah bahan organik, termasuk tumbuhan. Dekomposisi yang berhasil dicirikan dengan bahan yang difermentasikan hancur yang menunjukkan aktivitas bakteri yang tinggi. Sumber makanan dalam penelitian ini yang dimaksud adalah eceng gondok, agar proses dekomposisi cepat dilakukan pemotongan eceng gondok dengan menggunakan pisau atau gunting. Jika ukuran bahan terlalu besar maka dekomposisi akan berlangsung relatif lebih lama. Dalam penelitian awal ini dilakukan penggilingan dengan menggunakan blender.

\section{Komposisi media}

Komposisi media yang digunakan harus seimbang dengan larutan yang digunakan. Dalam pembuatan pupuk cair digunakan larutan EM4 dan dedak serta molase dan air secukupnya. Komposisi larutan EM4 harus sesuai dengan jumlah bahan yang akan digunakan. Apabila larutan EM4 kurang atau lebih sedikit, maka kemungkinan besar pupuk cair akan gagal dan bahan akan cepat membusuk. Dalam penelitian ini menggunakan sejumlah larutan EM4 sesuai dengan dalam resep. 


\section{Waktu pembuatan}

Pembuatan pupuk cair organik sebaiknya dilakukan pada waktu sore hari atau pagi hari dimana intensitas cahaya matahari relatif rendah dan kelembaban tidak terlalu tinggi. Misalnya dilakukan pada siang hari diusahakan tempat pembuatan pupuk dilakukan pada tempat yang terhalang intensitas cahaya matahari secara langsung. Kontaminansi dengan bakteri patogenik pada awal pembuatan akan sangat berbahaya, bakteri patogenik cenderung dapat berkembang biak dari suhu yang relatif tinggi. Bakteri patogenik juga dapat menyebar dari penggunaan bahan yang busuk. Dalam penelitian ini waktu pembuatan adalah pada saat siang hari. Namun berdasarkan hasil yang diperoleh memiliki ciri yang hampir sama dengan pupuk organik cair yang bagus.

Pada proses pembuatan pupuk cair organik, sangat dianjurkan agar bahan yang digunakan sebaiknya tidak busuk, hal ini dikarenakan pada bahan yang busuk kemungkinan terjadinya kontaminasi dari mikroba lain (mikroba merugikan) sangat besar. Hal ini tidak boleh terjadi, karena berdampak pada tingkat keberhasilan dalam proses pembuatan pupuk cair yang dibuat. Pada intinya di dalam bahan yang sudah mengalami pembusukan akan menghambat proses fermentasi yang dilakukan mikoorganisme yang menjadi starter yang telah di siapkan, sehingga proses fermentasi akan terhambat dan akhirnya tingkat keberhasilan bisa dapat dipastikan akan kecil. Pada penelitian ini ada bagian tanaman yang busuk masuk ke dalam sampel, hal ini dimungkinkan menjadi penyebab bau menyengat dari pupuk yang dihasilkan.

Adapun ciri-ciri dari pembuatan pupuk cair yang tidak berhasil (gagal) adalah dari bau yang dihasilkan, apabila berbau busuk dan menyengat pupuk itu dinyatakan gagal. Ciri ini dimiliki oleh sampel 1 dan sampel 2. Namun untuk sampel 3 dan sampel 4 bau yang dihasilkan tidak terlalu menyengat. Hal ini mungkin disebabkan karena adanya bahan yang digunakan sudah mengalami pembusukan, sehingga pada saat proses fermentasi berlangsung mikroba di dalamnya mengalami kompetisi dan pada akhirnya sama-sama mengalami kematian.

Selain itu terdapat faktor-faktor penyebab kegagalan dalam pembuatan pupuk cair ini yaitu ukuran tumbuhan yang dijadikan bahan organik yang terlalu besar, kurang tertutupnya wadah pengomposan sehingga air dan udara masih dapat masuk. Penyebab lainnya yang dimungkinkan adalah wadah pengomposan terkena sinar matahari langsung sehingga proses fermentasi menjadi terganggu.

Berdasarkan hasil data yang diperoleh, dapat dilihat pada sampel 1 dan sampel 2, dengan bahan yang digunakan yaitu menggunakan bahan kotoran kambing dan eceng gondok, dapat dikatakan kurang berhasil. Hal ini dapat 
dinilai dari bau pupuk cair, yang masih berbau menyengat, namun di sisi lain timbul jamur yang tumbuh diatasnya yang merupakan salah satu ciri yang dimiliki PKC yang baik. Untuk sampel 3 dan sampel 4 dengan bahan yang digunakan yaitu kotoran kambing fermentasi 20 hari dapat dikatakan mendekati berhasil. Hal ini juga dapat dilihat dari baunya yang tidak terlalu menyengat seperti pada sampel 1 dan sampel 2, karena bahan eceng gondok yang digunakan relatif lebih segar dibandingkan dengan yang digunakan untuk sampel 1 dan sampel 2 namun tidak dtumbuhi jamur.

Dari keempat sampel, dapat dikatakan bahwa sampel 3 dan sampel 4 telah mengalami proses fermentasi yang lebih baik jika dibandingkan dengan sampel 1 dan sampel 2. Hal tersebut dapat diketahui dari bau yang tidak terlalu menyengat. Dari studi literature yang dilakukan peneliti didapatkan keterangan bahwa pada umumnya pupuk organik cair memiliki bau yang kurang sedap. Hal ini bisa ditanggulangi dengan pemberian rempah-rempah berupa jahe, sereh, kulit bawang merah, kulit bawang putih pada sampel untuk mengurangi bau yang menyengat. Pada kondisi ideal pupuk yang berhasil diindikasi dengan bau yang wangi karena dapat dilihat sendiri bahwa masing-masing perlakuan menggunakan bahan-bahan yang memiliki bau yang sangat tidak sedap, akan tetapi setelah proses fermentasi berhasil, maka baunya akan menjadi wangi yang disebabkan oleh adanya proses fermentasi dari bakteri EM4.

Adapun saran yang diperoleh dari studi literatur untuk perbaikan pembuatan pupuk organik cair selanjutnya yaitu bahan yang digunakan tidak boleh busuk hal ini karena didalam bahan yang telah busuk terdapat bakteri yang nantinya pada saat pembuatan pupuk cair, bakteri tersebut akan bersaing dengan bakteri EM4 yang digunakan sebagai agen dekomposer bahan organik. Hal ini akan menyebabkan bakteri EM4 dalam pendengkomposisian bahan tersebut menjadi terhambat dan dapat juga menyebabkan bakteri EM4 menjadi mati karena kalah bersaing dengan bakteri yang ada pada bahan yang busuk.

Selain produk yang berupa pupuk cair, ampas dari hasil penyaringan dapat digunakan sebagai pupuk kompos padat. Berdasarkan hasil studi literatur yang dilakukan peneliti didapat data ciri pupuk organik padat yang bagus sebagai bahan pembanding dengan hasil yang diperoleh dari penelitian adalah sebagai berikut:

1. Bau dan Aroma Pupuk Organik Padat

Pupuk organik yang bagus selalu berbau harum seperti bau tanah menandakan bahwa proses fermentasi aerobiknya sudah selesai. Pada penelitian ini hasil yang didapatkan masih berbau seperti kotoran atau bau pesing sehingga belum bisa digunakan secara langsung karena ini akan menimbulkan fermentasi 
lanjutan dalam tanah yang bisa menyebabkan terganggunya pertumbuhan tanaman. Untuk menanggulangi hal ini masih memerlukan tambahan EM4 agar bahan organik bisa diuraikan dan diangin-anginkan sehingga didapatkan kompos padat yang kering dan dapat digunakan sebagai pupuk.

2. Warna pupuk organik kehitam-hitaman.

Seperti warna humus menandakan bahwa pupuk organik tersebut sudah benar benar matang. Pada penelitian ini warna pupuk masih coklat atau kehijauhijauan tanda proses fermentasi belum selesai.

3. Tes kantong plastik

Tes sederhana dengan memasukkan produk pupuk ke dalam kantong plastik dalam keadaan lembab (bila produk kering, dibasahi dulu kira kira kadar air 20 $\%$, ditutup rapat rapat kedap udara dan dibiarkan dalam suhu kamar selama 1 minggu. Bila bentuknya masih baik dan baunya masih tetap seperti bau tanah, menandakan bahwa pupuk organik tersebut sudah benar-benar matang.

Hal ini akan dilakukan pada saat didapatkan pupuk padat yang benar-benar kering.

4. Tes perkecambahan

Pupuk organik yang benar bila diatasnya ditaruh benih sehat, maka benih bisa tumbuh dengan baik. Hal ini akan dilakukan pada saat didapatkan pupuk padat yang benar-benar kering.

5. Suhu

Pupuk organik yang telah matang mempunyai suhu rendah yang stabil walaupun disimpan dalam waktu yang lama. Hal ini bisa dilakukan dengan memasukkan tangan disela-sela tumpukan karung pupuk. Pupuk yang benar terasa dingin di tangan.

Hal ini akan dilakukan pada saat didapatkan pupuk padat yang benar-benar kering.

6. Tes Gumpalan

Pupuk organik murni akan mudah sekali menggumpal tetapi juga mudah sekali terurai. Pupuk organik yang ditambahi bahan lain seperti Clay (semacam serbuk liat untuk memudahkan granulasi) dan Dolomit terlalu banyak, setelah dikepal akan sulit kembali terurai.

Hal ini akan dilakukan pada saat didapatkan pupuk padat yang benar-benar kering. Analisis terhadap pupuk padat yang dihasilkan akan dilanjutkan pada kegiatan laboratorium berikutnya.

Selanjutnya kegiatan pengabdian kepada masyarakat dilaksanakan dengan tahapan sebagai berikut:

1. Sosialisasi 
2. Praktik pembuatan pupuk kompos cair berbahan dasar enceng gondok

3. Pelatihan pengemasan pupuk kompos cair

Pelaksanaan kegiatan pengabdian masyarakat ini didukung oleh stake holder yaitu pihak Kelurahan Kaligawe Kota Semarang. Lokasi kegiatan bertempat di RW X yang diikuti oleh warga masyarakat. Adapun sebaran profesi peserta kegiatan ini cukup bervariasi, mulai dari karyawan swasta hingga ibu-ibu rumah tangga yang tergabung dalam kelompok PKK RW.

\section{Kegiatan Tahap 1: Sosialisasi pengolahan eceng gondok menjadi pupuk kompos cair}

Tahapan pertama kegiatan pengabdian dengan narasumber Dr. Lianah, M.Pd dimulai dengan sosialisasi ke peserta tentang pupuk cair yaitu manfaat dan cara pembuatannya. Kegiatan awal ini dihadiri oleh perangkat kelurahan Kaligawe, yaitu Lurah, sekretaris kelurahan, ketua LPMK dan tim penggerak PKK Kelurahan.

Pada sesi materi, narasumber menyampaikan tentang pentingnya pelestarian lingkungan hidup. Dalam kehidupan sehari-hari banyak dijumpai bahan-bahan yang dipandang sebagai gulma dan juga dipandang sebagai limbah yang salah satunya timbul karena adanya pengembangan teknologi. Bahan-bahan tersebut dipandang sebagai bahan yang berpotensi mengganggu kesetimbangan alam yang pada akhirnya mengganggu kelestarian lingkungan. Sebagai manusia yang dikaruniai akal budi seyogyanya memikirkan solusi atas permasalahan ini. Dewasa ini para peneliti mencoba untuk mengembangkan teknologi yang ramah lingkungan. Salah satu upaya yang dilakukan adalah mengelola limbah dan gulma agar dapat menjadi bahan yang berdaya guna melalui program recycle, reuse, reduce.

Bahan alam berupa tumbuhan yang dianggap gulma sekarang ini juga makin marak dimanfaatkan untuk bahan kerajinan, salah satunya adalah bahan eceng gondok. Berdasarkan informasi yang diperoleh dari penelusuran literature ternyata eceng gondok juga memiliki kandungan nutrisi yang tinggi dan sangat berpotensi untuk dijadikan bahan pupuk organik cair. Narasumber juga menyampaikan beberapa pengalaman dalam membuat pupuk organik, diantaranya adalah pembuatan pupuk organik padat (bokashi). Beberapa hal mengenai tips serta teknis pembuatan dan penggunaan pupuk baik dalam bentuk padat maupun cair juga dipaparkan oleh narasumber.

Selanjutnya narasumber menyampaikan tentang prosedur pembuatan pupuk kompos cair. Setiap peserta diberi handout berisi ringkasan materi tentang prosedur pembuatan pupuk kompos cair.

Narasumber juga menyampaikan berbagai contoh pemanfaatan bahanbahan limbah yang didaur ulang, diantaranya limbah plastik yang bisa dijadikan 
bahan kerajinan tangan bisa berupa tas, dompet dan sebagainya. Peserta sosialisasi mengikuti sesi dengan sangat antusias. Beberapa diantaranya menyampaikan kepada narasumber bahwa mereka sangat ingin mendapatkan pelatihan mengenai daur ulang bahan-bahan limbah.

\section{Kegiatan Tahap 2: Praktik pembuatan pupuk cair dari bahan eceng gondok}

Kegiatan tahap kedua dengan narasumber Kusrinah, M.Si. Kegiatan tahap 2 dimulai dengan pembekalan singkat tentang teknis pembuatan pupuk kompos cair. Bahan eceng gondok diperoleh dari kolam yang berada di dekat lokasi kegiatan pengabdian. Peserta dibagi menjadi delapan kelompok. Selanjutnya peserta melakukan praktik pembuatan pupuk organik cair sesuai dengan prosedur yang telah diberikan oleh narasumber. Pelaksanaan kegiatan praktik ini dibantu oleh para asisten narasumber yang memandu setiap kelompok secara intensif.

Bahan-bahan pupuk yang dicampur di dalam drum plastik selanjutnya disimpan di dalam ruangan untuk difermentasikan selama 2 pekan. Setelah masa fermentasi selesai dilakukan pengecekan terhadap tingkat keberhasilan pembuatan pupuk. Selanjutnya dilakukan penyaringan untuk memisahkan bagian cair dan bagian padat dari pupuk. Pupuk yang sudah dibuat didiamkan selama satu pekan untuk menghilangkan aroma dan gas yang timbul akibat proses fermentasi. Untuk bahan cair dapat digunakan sebagai pupuk organik cair, sedangkan bahan padat dikeringkan yang selanjutnya digunakan sebagai pupuk padat.

\section{Kegiatan Tahap 3: Pengemasan dan Teknik Pemasaran}

Kegiatan tahap ketiga dengan narasumber Agus Guntoro, S.Pd berisi materi dan pelatihan tentang teknik pengemasan dan pemasaran. Dalam sesi ini narasumber menyampaikan materi tentang sejarah perkembangan pengemasan produk dan peran pemasaran produk. Pada materi sejarah perkembangan pengemasan, narasumber menyampaikan tentang fungsi pengemasan, standar pengemasan produk, konsep pengemasan yang baik, fungsi label dan standar isi pelabelan kemasan.

Pada materi peran pemasaran, narasumber menyampaikan fungsi informasi dan promosi, target pemasaran dan faktor-faktor yang menentukan keputusan konsumen untuk membeli barang.

Narasumber banyak memberikan motivasi kepada peserta agar bisa percaya diri untuk menjadi enterpreneur. Peserta sangat antusias dalam mengikuti sesi dan banyak berkonsultasi mengenai cara memulai usaha kecil. 


\section{KESIMPULAN DAN REKOMENDASI}

Pelatihan dan pendampingan ini perlu ditindak lanjuti untuk tahapan tahun berikutnya untuk lebih menyempurnakan.

Pemberian motivasi perlu mendapat porsi lebih untuk membangkitkan semangat berkembang pada masyarakat Karang Kimpul Kelurahan Kaligawe.

\section{DAFTAR PUSTAKA}

Alex S. 2012. Sukses Mengolah Sampah Organik Menjadi Pupuk organik. Pustaka Baru Press.Yogyakarta.

Hadisuwito, S. 2007. Membuat Pupuk Kompos Cair. AgroMedia Pustaka. Yogyakarta

Kholidiyah, Noviana. 2010. Respon Biologis Tumbuban Eceng gondok (Eichornia crassipes Solms) Sebagai Biomonitoring Pencemaran Logam Berat Cadmium (Cd) Dan Plumbum (Pb) pada Sungai Pembuangan Lumpur Lapindo, Kecamatan Porong, Kabupaten Sidoarjo. UIN Maliki. Malang.

Kusumaningtyas, R. 2012. Pengelolaan Limbah Pertanian. Fakultas Pertanian. Universitas Jember.

Marianto, Lukito A. SP. 2003, Tanaman Air, Agro Media Pustaka. Yogyakarta Pandey.B.P.1980. Plant Anatomi, New Delhi: S Chard dan Co, Ltdramnage Sastroutomo, S. S. 1991. Ekologi Gulma. PT. Gramedia Pustaka Utama. Jakarta.

Sugeng, Wahyudi. 2013. Bikin Kompos dari Eceng Gondok. http://rajakomposcair.blogspot.com/. Diakses tanggal 20 April 2015

Tim Penyusun Departemen Agama RI, 2006. Al-Qur'an dan Terjemahannya, Penerbit Diponegoro. Bandung

Water Hyacinth, Proceed Syimposium on Pest Ecology and Pest management, SeameoBiotrop, Bogor, Indonesia. 